\title{
Znanstvena pismenost i stavovi prema znanosti u Hrvatskoj
}

\author{
Adrijana ̌́uljok \\ Institut za društvena istraživanja u Zagrebu, Hrvatska \\ e-mail:adrijana@idi.hr
}

SAŽETAK U ovome radu propituju se međuodnos znanstvene pismenosti i stavova javnosti prema znanosti u Hrvatskoj te njihove sociodemografske odrednice. Istraživanje je provedeno metodom osobnog anketiranja u sklopu omnibus istraživanja na reprezentativnom višeetapnom stratificiranom uzorku od 1000 stanovnika RH. Zaključci ove studije ukazuju na nisku razinu znanstvene pismenosti, ali i dalje pretežno pozitivne stavove prema znanosti, s nekim naznakama retradicionalizacije. Nalazi ukazuju i na postojanje značajne, ali slabe veze između razine znanstvene pismenosti i (pozitivnih) stavova prema znanosti, što je u skladu s nalazima inozemnih istraživanja.

Ključne riječi: javno razumijevanje znanosti, znanstvena pismenost, stavovi prema znanosti, model deficita.

\section{Uvod}

Prva istraživanja odnosa znanosti i javnosti u svijetu javljaju se u drugoj polovici 20. stoljeća, ali se tek osamdesetih godina intenziviraju i institucionaliziraju pod zajedničkim nazivom javno razumijevanje znanosti (engl. public understanding of science). Tema (međuodnosa) znanstvene pismenosti i stavova prema znanosti, kao dio javnog razumijevanja znanosti, i dalje izaziva veliki interes ne samo znanstvenika nego i društva jer je riječ o pitanju koje ima višestruke (znanstvene, socioekonomske te političke) implikacije. Većina razvijenih zemalja uključila je znanstvenu kulturu, pismenost ili javno razumijevanje znanosti ${ }^{1}$ kao jedan od ciljeva i principa svoje znanstvene i teh-

1 Burns i sur. (2003.) upozoravaju da se termini „javno razumijevanje znanosti“, „znanstvena pismenost“ ili „znanstvena kultura“ često pogrešno rabe kao sinonimi. Korištenje različitih termina, odnosno terminološka neujednačenost i nejasnoća u ovom istraživačkom području, kada se za iste pojave koriste različiti nazivi i obrnuto, dijelom je rezultat činjenice da je javno razumijevanje znanosti (engl. public understanding of science - PUS) mlado istraživačko područje, ali i „pokret“, odnosno oblik mobilizacije znanstvenika.

Copyright (C) 2020 Institut za društvena istraživanja u Zagrebu - Institute for Social Research in Zagreb Sva prava pridržana - All rights reserved 
nološke politike (Godin i Gingras, 2000.), povezujući ih i s donošenjem „ispravnih“ odluka kojima će osigurati ekonomski, politički i kulturni razvoj (Holton, 1993.; Michael, 1998.; Laugksch, 2000.). U razvijenim zemljama izdvajaju se znatna sredstva i napori u području istraživanja, ali i promicanja znanstvene pismenosti i pozitivnih stavova prema znanosti kroz npr. javnu popularizaciju ${ }^{2}$ znanosti, dijaloge znanstvenika i javnosti, poticanje javne participacije, obrazovne politike itd. Kada je u pitanju Hrvatska, zamjetni su početni napori na tom području, iako i dalje vrlo skromni. ${ }^{3}$

Iako su istraživanja odnosa znanosti i javnosti u svijetu brojna te se provode od druge polovice prošloga stoljeća, u Hrvatskoj su slabo zastupljena te možemo reći da se nalaze u početnoj fazi. Prva ozbiljnija istraživanja odnosa znanosti i javnosti u Hrvatskoj, odnosno javnih percepcija znanosti napravljena su početkom 2000-ih (vidi Prpić, 2005., 2007.; Brajdić Vuković i Šuljok, 2005.), no i ona ostaju obuhvatom ograničena „ostavljajući znanstvenu pismenost, interese i mišljenje o nekim konkretnim problemima znanstveno-tehnološkog razvoja zasada po strani“ (Prpić, 2005.: 241). Tema koja je činila jezgru PUS istraživanja u svijetu, međuodnos i veza znanstvene pismenosti i stavova prema znanosti te njihovih odrednica, u Hrvatskoj nije istraživana. Stoga je cilj ove studije analizom međuodnosa znanstvene pismenosti i stavova prema znanosti u Hrvatskoj proširiti empirijske uvide u tome području kao osnovu za daljnja istraživanja, ali i osvrnuti se na postojeće teorijske koncepte/modele.

\section{Znanstvena pismenost}

Znanstvena pismenost jedan je od temeljnih koncepata istraživačkog područja javnog razumijevanja znanosti (Paisley, 1998.; Bauer, 2015.). Termin je u literaturu uveden pedesetih godina prošlog stoljeća u članku pod naslovom „Znanstvena pismenost: njezino značenje za američku školu“ (Laugksch, 2000.), što implicira njegovu edukativnu ulogu. No znanstvena pismenost puno je složeniji fenomen koji obuhvaća više komponenti, te je definiranje i konceptualizacija toga pojma potrajala uslijed različitih gledišta i prijepora (za više vidjeti u: Laugksch, 2000.; Miller, 1983.). ${ }^{4}$ Početkom

2 Iako je riječ o terminu koji je vrlo raširen u svakodnevnom jeziku, sve se više izbjegava zbog negativnih konotacija na koje su ukazivali brojni istraživači. One su ponajprije vezane uz shvaćanje komunikacije znanosti kao jednosmjerne difuzije informacija, a ne višesmjernog procesa kojem je cilj poboljšanje dijaloga, odnosno jačanje društvene diskusije o znanstvenim pitanjima.

3 Primjerice, u sklopu Strategije obrazovanja, znanosti i tehnologije „Nove boje znanja“ na javno razumijevanje znanosti gleda se kao sredstvo/smjernicu za ostvarivanje strateških ciljeva (no ne i kao zaseban cilj). Predviđena su financijska sredstva za programe popularizacije znanosti te je izrađen Akcijski plan „Znanost i društvo“. Zamjetno je i sudjelovanje u programima Obzora 2020., kao što je Europska noć istraživača. No (oskudnim) policy mjerama i dalje dominira tradicionalni pristup javnom razumijevanju znanosti i shvaćanje javnosti kao pasivne i nedovoljno informirane.

${ }^{4}$ Mnogi istraživači dali su doprinos konceptualizaciji tog pojma. Primjerice radovi Shena (1975.), koji razlikuje praktičnu, kulturalnu i građansku (engl. civic) znanstvenu pismenost i Shamosa (1995.), koji definira kulturalnu, funkcionalnu i „pravu“ znanstvenu pismenost (prema Laugksch, 2000.). 
osamdesetih godina Miller (1983.) konceptualizira i predlaže jednu od najraširenijih definicija znanstvene pismenosti - višedimenzionalan koncept građanske znanstvene pismenosti (engl. civic scientific literacy) koji obuhvaća (a) poznavanje osnovnih znanstvenih činjenica (tzv. udžbeničko znanje), (b) razumijevanje znanstvene metode i (c) uvažavanje pozitivnih utjecaja znanosti i tehnologije za društvo. Sam Miller definira (građansku) znanstvenu pismenost kao „razinu razumijevanja znanstvenih i tehnoloških pojmova i konstrukata potrebnih za npr. čitanje dnevnih novina i razumijevanje suštine konkurentskih argumenata, odnosno za funkcioniranje u modernom industrijskom društvu“".

No Millerov model znanstvene pismenosti naišao je i na kritike. Neke od glavnih kritika, koje upućuju socijalno-konstruktivistički orijentirani istraživači (primjerice Wynne, 1992., 1993.), su sljedeće: da su pokazatelji udžbeničkog znanja u svakodnevnom životu nevažni te da je shvaćanje komunikacije između znanstvenika i javnosti kao jednosmjerne pogrešno. U kasnijim radovima Miller napušta trodimenzionalni model znanstvene pismenosti u korist dvodimenzionalnog modela, odnosno isključuje dimenziju utjecaja znanosti na pojedinca i društvo jer uviđa značajne varijacije među zemljama. No među istraživačima postoji suglasje da pouzdan dvodimenzionalni instrument može biti koristan za međunarodne usporedbe i istraživanja (Miller, 1998.). Millerova definicija znanstvene pismenosti i danas je, iako izložena kritikama posebice iz redova socijalnih konstruktivista, vrlo raširena. $U$ ovom radu, pri operacionalizaciji znanstvene pismenosti, poslužit ćemo se upravo Millerovim modelom gradanske znanstvene pismenosti s naglaskom na prvoj dimenziji, odnosno poznavanju znanstvenih činjenica, što je jedan od najčešće korištenih pristupa.

Istraživanja znanstvene pismenosti pretežno se vežu uz prvu te dijelom drugu fazu u razvoju istraživanja odnosa znanosti i javnosti, kako ih definira Bauer (2003.). Dok prvim dvjema fazama (1960. - 1970. te 1985. - 1990.) istraživanja znanstvene pismenosti i javnih stavova prema znanosti dominira paradigma znanjem deficitarne javnosti, uslijed čega se javljaju nedovoljno pozitivni stavovi prema znanosti, treća faza obilježena je teorijsko-metodološkom promjenom, odnosno pomicanjem deficita prema znanstvenicima koji gube javno povjerenje (Bauer, 2003.). Drugim riječima, istraživanja znanstvene pismenosti u velikoj mjeri počivaju na temeljima "tradicionalne (pozitivističke) paradigme" (Michael, 2002.), koju su obilježila pretežno kvantitativna istraživanja znanstvene pismenosti i stavova prema znanosti te model deficita znanja. Navedeni model deficita znanja naglašava prvenstveno kognitivne aspekte javnog razumijevanja znanosti i smatra da je nedovoljna znanstvena pismenost, deficit znanja, glavni uzrok negativnih stavova prema znanosti te da je elementarno razumijevanje znanosti pretpostavka "prijateljski“ nastrojene javnosti. Drugim riječima, pretpostavka je bila da će javnost što više zna, što je informiranija, imati pozitivniji stav prema znanosti. Način kojim bi se to ostvarilo podrazumijevao je educiranje „pasivne i znanjem deficitarne" javnosti, odnosno asimetričnu, jednosmjernu (od vrha prema do- 
lje) komunikaciju od znanstvenika („znanstvene citadele“), kao vrhovnog proizvođača znanja u društvu, prema javnosti (Irwin i Michael, 2003.).

Tradicionalni pristup bio je i ostao predmetom brojnih prigovora kao znanstvenocentričan i paternalistički. Dva su glavna smjera prigovora. Prvi je usmjeren na to da znanost nije neproblematično tijelo znanja, dok je drugi upućen konceptu ignorantske, monolitne i pasivne javnosti te jednosmjernoj komunikaciji. S druge strane, kritički, konstruktivistički pristup, velikim dijelom utemeljen na socijalno-konstruktivističkoj orijentaciji, obilježile su kvalitativne studije te se fokusira na kontekstualne i interpretativne dimenzije javnog razumijevanja znanosti i višesmjernu komunikaciju znanosti (Michael, 2002.). Posebice se kritički odnosi prema istraživanjima utemeljenima na naglašavanju znanja znanstvenih činjenica i procesa, tj. studijama znanstvene pismenosti koje nisu uzimale u obzir društvenu dimenziju spoznaja i kulturni kontekst te komuniciranje društveno „irelevantnih“ informacija, specijaliziranih znanja, nebitnih u svakodnevnom životu, što se vraća negativnim stavovima javnosti (Wynne 1992., 1993.). Nadalje, najčešće su kritike kako odnos između pismenosti i stavova nije linearan, komunikacija između znanstvenika i javnosti mora biti višesmjerna te se naglašava važnost sociokulturnog konteksta i lokalnih znanja u tom odnosu, koje je tradicionalni model ignorirao. No i kritički pristup izložen je kritikama zbog relativiziranja postojanja ikakvog konsenzusa, parcijalnosti i otežavanja generalizacija. Stoga se ti modeli, kao i dominantne teme i istraživački pristupi, ne trebaju promatrati isključivo kao suprotstavljeni, nego nadopunjavajući.

\section{Pregled dosadašnjih istraživanja}

Znanstvena pismenost postaje temom brojnih istraživanja u drugoj polovici 20. stoljeća, većinom na području SAD-a (a kasnije i šire), kada jačaju kritički stavovi prema znanosti i tehnologiji u razvijenim zemljama, jer se smatralo da je upravo neadekvatna znanstvena pismenost dovela do pojave kritičkih tonova i propitivanja znanosti te posljedično negativnih stavova prema znanosti i time ugrozila javno povjerenje i financiranje znanosti.

Zbog toga su mnogobrojna istraživanja znanstvene pismenosti (najčešće tzv. udžbeničkog znanja) neizbježno povezana s istraživanjima stavova prema znanosti (Evans i Durant, 1995.; Miller i sur., 1997.; Sturgis i Allum, 2004.) i utemeljena na tradicionalnoj paradigmi i modelu deficita znanja.

No teza o uzročno-posljedičnoj i linearnoj vezi stavova i znanja utemeljena na modelu deficita od sredine 90-ih godina sve je više propitivana (Allum i sur., 2008.) i kritizirana (vidi Wynne, i dr. 1992., 1993.; Pardo i Calvo, 2002.), kao i (dijelom) demantirana pojedinačnim studijama, iako je zbog proturječnosti nalaza povremeno teško izvesti jednoznačne zaključke. 
Kasnije studije (Durant i sur., 2000.) koje su kritički ispitale linearan odnos znanja i stavova ukazuju da ne postoji jednoznačan obrazac u odnosu pismenosti i stavova. U mnogim znanstvenim studijama, ali i javnim politikama, pretpostavljeno je da je znanstvena pismenost vrlo važna za razvoj pozitivnih stavova prema znanosti, a metaanaliza niza studija objavljenih u razdoblju od 1989. do 2004. godine, koju su napravili Allum i sur. (2008.), pokazuje slabu, ali značajnu vezu između razine znanja (znanstvene pismenosti) i javnih stavova prema znanosti. Neke studije potvrđuju tezu da znanstveno pismeniji pojedinci u većoj mjeri podržavaju znanost, no to nužno ne znači kauzalnu vezu (Evans i Durant, 1995.). Druga je istraživanja opovrgavaju, odnosno nalaze da su najviše razine znanja povezane s manje pozitivnim stavovima i zahtjevima za javnim participiranjem u donošenju odluka (Bucchi i Neressini, 2002.; Hisschemoller i Midden, 1999., prema Šuljok, 2011.). Istraživanje Evansa i Duranta (1995.) otkriva da iako pojedinci mogu podupirati znanost i gajiti pozitivne stavove prema znanosti općenito, kada su u pitanju moralno/etički spornija znanstvena istraživanja, kao što su primjerice u području embriologije, mogu izražavati otpor, odnosno negativne stavove, tj. visoka razina znanstvenih spoznaja ne mora uvijek biti pretočena u potporu znanosti (Roduta Roberts i sur., 2013.). Neke studije (Ho i sur., 2008., Allum i sur., 2014.) pokazuju i da vrlo religiozni ljudi koji su također dobro upoznati sa znanošću (znanstveno pismeni) imaju tendenciju gajiti negativnije stavove prema određenim znanstvenim temama od onih koji su manje znanstveno pismeni. No ta zapažanja samo potvrđuju da kognitivna razrada nije nužno ključni čimbenik pozitivnih stavova, nego pokazatelj njihove kvalitete/snage: znanje ojača stav da se odupre utjecaju i čini ga predvidljivijim ponašanjem bez obzira na smjer (Pomerantz i sur., 1995.). Odnosno, javnost koristi znanje na različite načine u skladu sa svojim već postojećim interesima i motivacijama (Allum i sur., 2014.).

Dakle, noviji nalazi pokazuju da razina znanja (znanstvene pismenosti) objašnjava malu količinu varijance, dok drugi čimbenici kao što su ideologija, vjerska uvjerenja i povjerenje te neke sociodemografske odrednice imaju tendenciju biti mnogo jači prediktori stavova (Allum i sur. 2008.; Ho i sur., 2008.; Gauchat, 2012.). To je osobito istinito $u$ ispitivanju veze između znanja i stavova o specifičnim kontroverznim pitanjima, tvrde Allum i suradnici (2008.). Istraživanja pokazuju i da pojedinci $s$ pozitivnijim stavovima prema znanosti imaju tendenciju biti obrazovaniji, imati viši socioekonomski status i biti muškog spola (Einsiedel, 1994.; Sturgis i Allum, 2001.; Miller, 2004.; Wellcome Trust, 2001., prema Roduta Roberts i sur. 2013.), iako Hayes i Tariq (2001.; 2000.) osporavaju utjecaj spola kada se uključe druge sociodemografske varijable u regresijske modele.

Još jedan iskorak prema složenijim konceptualnim i metodološkim pristupima razumijevanju odnosa znanosti i javnosti, pa tako i stavova javnosti, napravljen je zahvaljujući pokušajima povezivanja stavova i znanja s obiljě̌jima socioekonomskog i kulturnog konteksta određene zemlje (Pardo i Calvo, 2002.). Tako su studije pokazale 
značajne varijacije u nacionalnim stavovima prema znanosti, dovodeći u vezu razinu razvoja tj. razinu industrijalizacije društva i razinu podrške ili prihvaćanja znanosti (Bauer, 2009.). Ti nalazi otkrivaju da je korelacija znanja i stavova najniža u zemljama koje su ekonomski najnaprednije $\mathrm{i}^{5}$ u onim zemljama koje su najmanje razvijene, odnosno sugeriraju da odnos znanja i stavova nema linearan oblik, nego oblik krivulje. $\mathrm{Na}$ industrijskom stupnju razvoja, tvrdi Bauer, znanost se idealizira kao sredstvo socioekonomskog razvoja, i što građani više znaju o znanosti, njihovi su stavovi usklađeniji s tim stereotipom. I neka domaća istraživanja i nalazi (Prpić, 2007.) upućuju na tezu da su društveni korijeni većega povjerenja u znanost u razvojnim i modernizacijskim potrebama postsocijalističkih društava, kao i u tradiciji proznanstvenih stavova tipičnih za nekadašnje socijalističke zemlje (Bauer i sur., 2000.; Inönü, 2003.; Šporer, 2004.; Bauer i sur., 2006.). S druge strane, najrazvijenija društva postala su opreznija, skeptičnija i kritičnija u odnosu sa znanosti i tehnologijom (Bauer, 2009.). U postindustrijskim društvima znanost se uzima zdravo za gotovo, znanje je sve kompleksnije i specijaliziranije, a javnost sve skeptičnija i kritičnija u očekivanjima da će znanost donijeti napredak. Stoga, tvrde autori, više znanja može dovesti i do većeg skepticizma, ali i straha od znanstvenih poduhvata i njihovih implikacija, zbog izostanka pozitivnih kulturnih stereotipa, odnosno proznanstvene socijalizacije (Allum i sur., 2008.; Price i Peterson, 2016.).

Imajući na umu navedene postavke modela deficita, kao i kritike koje su mu upućene, pristupit ćemo analizi odnosa stavova prema znanosti i znanstvene pismenosti u Hrvatskoj.

\section{Ciljevi i metoda istraživanja}

Središnje pitanje ovog rada jest utvrditi međusobni odnos znanstvene pismenosti i stavova prema znanosti u Hrvatskoj, kao i njihove sociodemografske odrednice.

Pojedinačni ciljevi ovog istraživanja jesu:

1) utvrditi razinu znanstvene pismenosti

2) utvrditi sociodemografske determinante znanstvene pismenosti

3) utvrditi javne stavove prema znanosti i tehnologiji

4) te naposljetku utvrditi postoji li veza između znanstvene pismenosti i stavova prema znanosti, odnosno utvrditi prediktore stavova prema znanosti.

5 Tzv. „postindustrijska znanstvena kultura“, u kojoj je veza znanja, interesa i stavova niska i koja je karakteristična za ekonomski razvijene zemlje, naspram „industrijske znanstvene kulture“, karakteristične za zemlje u razvoju s visokom korelacijom između znanja, interesa i stavova (Bauer, 2009.). 
Istraživanje je provedeno 2014. godine metodom osobnog anketiranja u kućanstvu (licem u lice) u okviru omnibus istraživanja agencije za istraživanje javnog mnijenja Ipsos Puls.

Uzorak je obuhvatio tisuću stanovnika RH starijih od 15 godina. Riječ je reprezentativnom višeetapnom stratificiranom uzorku. Osim prema regiji i veličini naselja, struktura je još kontrolirana prema spolu, dobi i obrazovanju.

Znanstvena pismenost i opći stavovi prema znanosti ispitivani su pomoću modificiranih instrumenata koje su razvili J. Miller i Durant ${ }^{6}$ te se redovito koriste u NSF-ovim (National Science Foundation) i brojnim drugim znanstvenim, ali i (nacionalnim) javnomnijenjskim istraživanjima (npr. Eurobarometar). Poznati su i pod nazivom oksfordska skala (Oxford scale) i ATOSS - Attitude Toward Organized Science Scale. Pardo i Calvo (2002., 2004.) drže da je riječ o formalno i konceptualno slabim instrumentima (pouzdanost skale, preopćenitost tvrdnji, nedovoljna teorijska utemeljenost). Drugi pak sugeriraju nove instrumente za mjerenje znanstvene pismenosti na temelju medijskog sadržaja jer su upravo mediji glavni izvor informacija nakon prestanka školovanja (Brossard i Shanahan, 2006.). No s druge strane, kao što Pardo i Calvo (2002., 2004.) kasnije priznaju, oksfordska skala ostaje korisna kao približna mjera za varijacije u znanstvenoj pismenosti pojedinaca, društvenih skupina i kultura. Taj zaključak potkrepljuju i brojne studije koje su koristile inačicu oksfordske skale (npr. Evans i Durant, 1995.; Sturgis i Allum, 2004.).

Kada je u pitanju ispitivanje stavova, Pardo i Calvo (2002.) tvrde da su informacije o konstrukciji instrumenata i odabiru tvrdnji koje mjere kontinuum od pozitivnih prema negativnim stavovima (prema organiziranoj znanosti), tzv. ATOSS, nedostatne (odabir tvrdnji u većini je slučajeva vođen istraživačkim pitanjima) da bi se moglo govoriti o njihovoj valjanosti. Unatoč tome oni se u različitim oblicima (skraćenim, proširenim ili izvornim) koriste i osiguravaju određenu komparabilnost s prijašnjim studijama i među zemljama. Imajući na umu i kritike, ali i prihvaćenost i raširenost različitih verzija tih instrumenata unutar znanstvene zajednice i šire (riječ je o najčešće korištenim i citiranim instrumentima), odlučili smo ih opsegom prilagoditi potrebama ovog istraživanja i takve koristiti.

${ }^{6}$ Miller (1998.) navodi da je više od 100 konstrukata razvijeno u Projektu 2061 i potencijalno mogu biti uključeni u instrument kojim se mjeri znanstvena pismenost. Pretpostavlja se da je njihov konačan odabir prepušten stručnjacima/istraživačima (Brossard i Shanahan, 2006.). 


\section{Konstrukcija instrumenta}

U ovom istraživanju znanstvena pismenost ispitivala se pomoću osam tvrdnji. Konstrukcija testa znanstvene pismenosti kombinirala je tvrdnje raširene u javnomnijenjskim istraživanjima (oksfordska skala) s ciljem uravnoteženije zastupljenosti pitanja iz različitih znanstvenih disciplina. Pouzdanost skale izražena koeficijentom unutarnje konzistentnosti, Cronbach alfom, iznosi 0.63 , te se može smatrati prihvatljivom, osobito u komparaciji s drugim studijama. Npr. Bauer i Howard (2013.) utvrdili su da je Cronbachov alfa za mjerni instrument kojim se mjerila znanstvena pismenost pomoću 13 tvrdnji na razini EU-a iznosila 0.66 .

Ispitanici su na ponuđene tvrdnje mogli odgovoriti „točno/netočno“ ili „ne znam“ te im je dodjeljivana vrijednost 0 i 1 ( 1 u slučaju točnog odgovora). ${ }^{7} \mathrm{U}$ slučaju odgovora „ne znam“ dodjeljivana je također vrijednost 0 . Zbrajanjem je zatim konstruirana skala znanstvene pismenosti, raspona od 0 do 8 . Što je viši rezultat na skali, ispitanik je veći broj puta odgovorio točno na tvrdnju.

Instrument za mjerenje stavova prema znanosti i tehnologiji sastojao se od 23 tvrdnje i također je preuzet iz prethodnih istraživanja (npr. OST i Wellcome Trust, 2000.). Tvrdnjama su obuhvaćeni sljedeći aspekti - društvena uloga (i učinci) znanosti i tehnologije, javna participacija te etički aspekti. Ispitanici su trebali odrediti stupanj svog slaganja s ponuđenim tvrdnjama na peterostupanjskoj ordinalnoj ljestvici (Likertovog tipa). Iako neka istraživanja preferiraju četverostupanjske skale koje „prisiljavaju“ na izbor pozitivno/negativno, druga koriste klasične Likertove skale sa „srednjom“ opcijom držeći da one bolje odražavaju mišljenje/stav ispitanika. Iako cilj ove studije nije bio razvoj instrumenta za ispitivanja stavova javnosti prema znanosti, eksplorativnom faktorskom analizom ispitana je dimenzionalnost mjernog instrumenta te su izdvojena tri faktora čija je pouzdanost provjerena Cronbachovim alfa koeficijentom. Prve dvije ekstrahirane dimenzije imale su visoku pouzdanost $(0,797,0,754)$, dok je pouzdanost treće dimenzije bila niska, 0,415 .

Prikupljeni su i osnovni sociodemografski podaci ispitanika: spol (muškarac/žena), dob, veličina naselja (do 2000 stanovnika; 2000 - 10.000; 10.000 - 100.000; 100.000 i više stanovnika), stupanj obrazovanja (varijabla s 11 stupnjeva) i religioznost. Religioznost se ispitivala pomoću skale religijske samoidentifikacije koja se koristi duži niz godina u više domaćih istraživanja (npr. Bahtijarević, 1969.; Marinović Bobinac, 2005.; Marinović Jerolimov i Ančić, 2014.). Ispitanici su na skali od 1 do 6 mogli zaokružiti jednu od sljedećih opcija: uvjereni vjernik, prihvaćam sve što moja vjera uči; vjernik, premda ne prihvaćam sve što moja vjera uči; dosta razmišljam o tome, ali nisam načistu vjerujem li ili ne / nesiguran; prema religiji sam ravnodušan; nisam vjernik iako nemam ništa protiv vjere; nisam vjernik i protivnik sam vjere.

\footnotetext{
${ }^{7}$ Te su stavke pouzdane samo u kombinaciji, svaka izolirana pojedinačna tvrdnja ima malo značaja.
} 
Svi prikupljeni podaci obrađeni su u SPSS 20.0 deskriptivnom statistikom, multiplom regresijskom analizom te faktorskom analizom.

\section{Diskusija}

\section{Znanstvena pismenost $i$ sociodemografske determinante}

Kakva je razina znanstvene pismenosti te koje su njezine sociodemografske determinante prvo je pitanje na koje nastojimo odgovoriti. U tablici 1 nalazi se struktura odgovora (točno, netočno, ne znam), iskazana u postocima, na tvrdnje kojima se ispitivala znanstvena pismenost (podcrtani su točni odgovori).

Promotrimo li tablicu 1, u našem testu znanstvene pismenosti koji se sastojao od osam tvrdnji ispitanici su najviše bili upoznati s pitanjem, tj. najčešće su točno odgovarali na tvrdnju o kretanju Zemlje oko Sunca, a najrjeđe su točno odgovorili na pitanje o porijeklu radioaktivnosti. Najčešće su priznavali neznanje kod tvrdnje o količini gena koju dijelimo s drugim vrstama, što nije začudno jer je riječ, prvo, o tvrdnji koja nije učestalo korištena u testovima znanstvene pismenosti te, drugo, o znanstvenoj spoznaji koja je rjeđe prisutna $\mathrm{u}$ javnom tj. medijskom prostoru te je samim time manje poznata.

Tablica 1.

Znanstvena pismenost - struktura odgovora u postocima (\%)

\begin{tabular}{|l|c|c|c|}
\hline & Točno & Netočno & Ne zna \\
\hline Antibiotici ubijaju i viruse i bakterije. & 37,6 & $\underline{56,6}$ & 5,8 \\
\hline Prvi ljudi su živjeli u isto vrijeme kad i dinosaurusi. & 16,4 & $\underline{67,9}$ & 15,7 \\
\hline Konzumiranjem genetski modificiranog voća mogu se promijeniti osobni geni. & 39,2 & $\underline{44,2}$ & 16,6 \\
\hline Sva radioaktivnost na Zemlji potječe od čovjekova djelovanja. & 54.3 & $\underline{38.2}$ & 7.5 \\
\hline Majčini geni određuju spol djeteta. & 18.7 & $\underline{64.1}$ & 17.2 \\
\hline Čovjek dijeli više od polovice gena s miševima. & $\underline{27.6}$ & 38.3 & 34.1 \\
\hline Elektroni su manji od atoma. & $\underline{51.8}$ & 28.0 & 20.2 \\
\hline Zemlji treba mjesec dana da se okrene oko Sunca. & 16.6 & $\underline{70.5}$ & 13.0 \\
\hline
\end{tabular}

Od ukupnog uzorka 4,9\% ispitanika nije točno odgovorilo ni na jednu tvrdnju kojom se mjerila znanstvena pismenost, a samo 2,9\% odgovorilo je točno na sve tvrdnje. Ispitanici koji nisu odgovorili točno ni na jedno ili su točno odgovorili samo na jedno pitanje $(11,9 \%)$ pretežno su ženskog spola i starije životne dobi (58 godina) sa završenom samo osnovnom školom. U kategoriji onih koji su odgovorili točno na sva pitanja ili na njih sedam, dakle s jednim pogrešnim / „ne znam“ odgovorom $(11,4 \%)$, otprilike su podjednako zastupljena oba spola, mlađi su od prosjeka (41 godina) te češće imaju završen fakultet ili višu školu. 
Prosječan broj točnih odgovora iznosio je 4,2, što bi značilo da su u prosjeku na pola tvrdnji (47\%) ispitanici davali točan odgovor. Usporedimo li te nalaze s međunarodnim istraživanjima, iako instrumenti nisu u potpunosti komparabilni, možemo reći da je znanstvena pismenost u Hrvatskoj ispod razine znanstvene pismenosti, primjerice, u SAD-u ili prosjeka EU-a. Istraživanje provedeno 2012. godine u SAD-u pokazalo je da su američki ispitanici točno odgovarali u prosjeku na 5,6 tvrdnji (od 9), odnosno oko $62 \%$ (NSB). ${ }^{8}$ Pritom su ispitanici sa završenim diplomskim studijem imali tendenciju odgovoriti na veći broj pitanja ispravno, oko $80 \%$ u usporedbi sa $60 \%$ ispitanika s višom školom (NSB, 2012.). Hrvatska, prema Eurobarometrovim (2005.) podacima, ima nešto lošiji rezultat od prosjeka EU-a na testu znanstvene pismenosti (EU 25 - 66\% u usporedbi s HR - 63\% točnih odgovora). Ukupno, bolje su rezultate postizali ispitanici iz razvijenijih europskih zemalja. Nadalje, kada se analiziraju sociodemografski pokazatelji, vidljivo je da su muškarci, mlađi ispitanici, obrazovaniji te oni koji su još u procesu formalnog obrazovanja postizali veći broj točnih odgovora (Eurobarometar, 1992., 2005.). Osim toga, podaci Eurobarometra iz 2005. godine sugeriraju da ispitanici koji učestalo pohađaju vjerske obrede (jednom tjedno) u prosjeku imaju manje točnih odgovora (54\% na razini EU 25) u odnosu na one koji nikad ne pohađaju vjerske obrede (70\%). Drugim riječima, učestalost pohađanja vjerskih obreda povezana je s brojem točnih odgovora, odnosno religiozniji pojedinci u prosjeku su rjeđe odgovarali ispravno.

I druga istraživanja pokazuju da neke sociodemografske odrednice mogu biti važan prediktor znanstvene pismenosti, ali i stavova prema znanosti. Tako ukazuju na to da viša razina (formalnog) obrazovanja, socijalna klasa / socioekonomski status, dob te spol (muški) imaju tendenciju biti pozitivno povezani sa znanstvenom pismenošću (te stavovima prema znanosti i tehnologiji) (Einsiedel, 1994.; Bauer i sur., 2000.; Miller, 2004.; Allum i sur., 2008.). Prema Milleru (2004.) je pak najpouzdaniji prediktor znanstvene pismenosti pohađanje (barem triju) znanstvenih kolegija tijekom preddiplomskog studija.

Primjenom multiple regresijske analize, enter metodom, testirali smo jesu li i koji sociodemografski pokazatelji značajni prediktori za objašnjavanje razine znanstvene pismenosti. Kao prediktorske varijable koristili smo sljedeće sociodemografske pokazatelje: religioznost, dob, veličinu naselja, spol i obrazovanje.

$\mathrm{U}$ tablici 2 prezentirani su nalazi regresijske analize. Rezultati regresijske analize ( $\operatorname{sig}=0,000 ; \mathrm{F}=46,64)$ pokazuju da prediktorski sklop tumači $19,1 \%\left(\mathrm{r}^{2}=0,191\right)$ kriterijske varijable uz tri značajna prediktora - dob, obrazovanje i religioznost.

8 Testovi znanstvene pismenosti mogu biti i pristrani utoliko što postoji vjerojatnost da rezultati odražavaju konkretnu znanstvenu bazu neke zemlje, npr. ako zemlja ima razvijeno područje biotehničkih znanosti koje je prepoznatljivo u javnosti, veća je vjerojatnost da će ispitanici biti informirani o tom području (prema Bauer, 2008.). 
Tablica 2.

Regresijska analiza - sociodemografske determinante znanstvene pismenosti

\begin{tabular}{|l|c|c|}
\hline R Square $=0,191$ & Stand. beta koeficijent & Sig. \\
\hline Spol &, 001 &, 969 \\
\hline Dob &,- 144 &, 000 \\
\hline Stupanj obrazovanja &, 323 &, 000 \\
\hline Veličina naselja &, 051 &, 097 \\
\hline Religioznost &, 081 &, 008 \\
\hline
\end{tabular}

Iako mnoge studije ukazuju na to da spol može biti prediktor razine znanstvene pismenosti, na način da muškarci postižu bolje rezultate na upitniku znanstvene pismenosti', nalazi nisu uvijek jednoznačni (Hayes i Tariq, 2000.; Miller, 2004.; von Roten, 2004.). Novija istraživanja sugeriraju da žene pokazuju veći interes za teme iz biomedicinskih znanosti te zaštite okoliša, pa su posljedično i bolje u poznavanju biomedicinskih činjenica, dok su muškarci bolji u području prirodnih i tehničkih znanosti kao što su fizika, istraživanja svemira, inovacije - tablica 3 (NSB, 2016.).

Tablica 3.

Postotak točnih odgovora na činjenično znanje u fizici i srodnim disciplinama te biološkim znanostima, po spolu: 1999. - 2014. (NSB, 2016.)

\begin{tabular}{|l|c|c|c|c|c|c|c|c|}
\hline Znan. pismenost - fizika i srodne discipline & 1999. & 2001. & 2004. & 2006. & 2008. & 2010. & 2012. & 2014. \\
\hline Muškarci & 72 & 73 & 73 & 74 & 74 & 73 & 75 & 74 \\
\hline Žene & 57 & 59 & 55 & 59 & 61 & 60 & 61 & 63 \\
\hline Znan. pismenost - biologija i srodne discipline & & & & & & & & \\
\hline Muškarci & 59 & 61 & 62 & 63 & 60 & 62 & 59 & 63 \\
\hline Žene & 61 & 65 & 65 & 66 & 64 & 64 & 62 & 67 \\
\hline
\end{tabular}

Zbog toga je prilikom istraživanja i analiziranja znanstvene pismenosti bitan kolikotoliko uravnotežen odabir indikatora udžbeničkog znanja / znanstvene pismenosti iz različitih područja kako bi se izbjegla pristranost koja proizlazi iz različitih interesa za različita znanstvena područja. Naši nalazi pokazuju da spol nije značajan prediktor znanstvene pismenosti, odnosno nismo identificirali razlike među spolovima u razini znanstvene pismenosti. Muškarci su u prosjeku $(4,3)$ neznatno češće odgovorili točno od žena $(4,1)$. Prosječni rezultati na skali znanstvene pismenosti prema sociodemografskim varijablama dani su u tablici $3 a$.

9 NSF-ova studija pokazuje da su muškarci u prosjeku imali $70 \%$ točnih odgovora, dok su žene točno odgovorile na 60\% pitanja (NSB, 2012., 2014.). 
Tablica 3 a.

Indeks znanstvene pismenosti (prosječni rezultat)

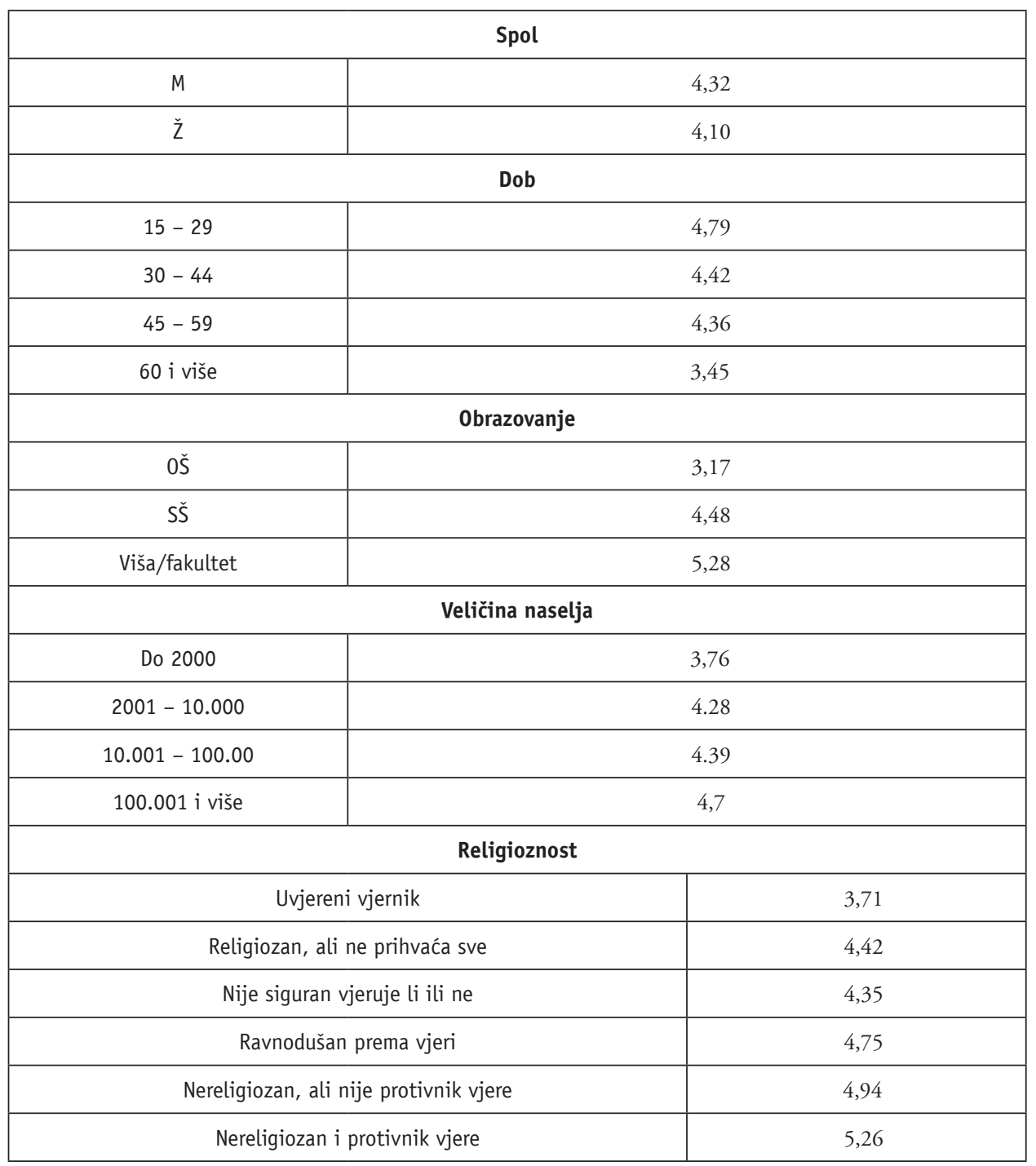

Veličina naselja u kojem ispitanik živi također se nije pokazala kao značajan prediktor znanstvene pismenosti, iako su ispitanici iz (naj)manjih naselja postizali u prosjeku lošiji rezultat. Kako seoska naselja karakterizira i starije stanovništvo te niža obrazovna struktura, razlika je posljedica tih sociodemografskih obilježja, a ne same veličine naselja, što je vidljivo iz tablice 2 , odnosno činjenice da se kao značajni prediktori pojavljuju upravo dob, obrazovanje te religioznost ispitanika na skali religijske samoidentifikacije. Dob kao prediktorska varijabla ima negativan beta ponder (tablica 2), što sugerira da su (naj)stariji ispitanici postizali lošiji rezultat na skali znanstvene pisme- 
nosti, a osobito u odnosu na najmlađu skupinu ispitanika (do 29 godina) (tablica 3a). Kao značajan prediktor razine znanstvene pismenosti pojavljuje se i obrazovanje. Odnosno, što je viši stupanj formalnog obrazovanja ispitanika, ispitanici su postizali bolji skor na skali znanstvene pismenosti (tablica 3a). I druga međunarodna istraživanja pokazala su da je razina znanstvene pismenosti u snažnoj vezi s razinom obrazovanja, ali i obrazovanjem iz područja matematike i znanosti (Miller, 2004.; Eurobarometar, 2005.; NSB, 2014.). Također su potvrdila da su (naj)stariji ispitanici (stariji od 65 godina) u odnosu na (naj)mlađe značajno manje puta točno odgovarali na tvrdnje kojima se mjerila znanstvena pismenost. Budući da mlađi ispitanici, u prosjeku, posjeduju veću razinu formalnog obrazovanja nego stariji odrasli ispitanici, to nije iznenađujuće. No s druge strane postavili su i pitanje je li povezanost dobi i tzv. činjeničnog znanja primarno posljedica starenja, kohortnih razlika u pismenosti ili drugih čimbenika. Analiza istraživanja koja su provedena između 1979. i 2006. godine pokazala je da je javno razumijevanje znanosti raslo tijekom vremena i po generaciji, čak i nakon kontrole formalne razine obrazovanja (Losh, 2010., 2012.; NSB, 2016.).

Naposljetku, kao značajan prediktor razine znanstvene pismenosti pojavljuje se i religioznost ispitanika, ispitivana kroz skalu religijske samoidentifikacije. Oni ispitanici koji sebe vide kao manje religiozne ili nereligiozne u prosjeku su postizali bolji rezultat na skali znanstvene pismenosti (tablica 3a), što je nalaz koji je u skladu s međunarodnim istraživanjima (Eurobarometar, 2005.).

Iz navedenih nalaza možemo sažeti da su značajni prediktori znanstvene pismenosti u ovom istraživanju dob, obrazovanje i religioznost, što je nalaz koji je u skladu s nalazima većine međunarodnih studija, uz iznimku spola, čija značajnost nije potkrepljena podacima ove studije.

\section{Stavovi javnosti prema znanosti}

Kako bismo dobili uvid u stavove javnosti prema znanosti te utvrdili postoje li različiti tipovi gledišta o znanosti, analizirali smo latentnu strukturu javnih stavova prema znanosti. No prvo ćemo u tablici 4 prikazati strukturu odgovora ispitanika na 23 tvrdnje kojima smo ispitivali stavove prema znanosti i prosječne rezultate ispitanika na tim skalama te kratko prokomentirati najbitnije nalaze. 
Tablica 4.

Stavovi prema znanosti - struktura odgovora u postocima te prosječni rezultat

\begin{tabular}{|c|c|c|c|c|c|c|c|}
\hline & 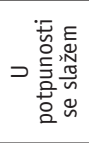 & 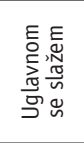 & 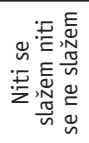 & 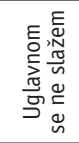 & 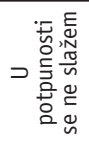 & $\Sigma$ & คิ \\
\hline $\begin{array}{l}\text { Što više znam o znanosti, zabrinutiji/a sam za } \\
\text { budućnost čovječanstva. }\end{array}$ & $13,8 \%$ & $41,8 \%$ & $27,2 \%$ & $13,6 \%$ & $3,6 \%$ & 2,5 & 1 \\
\hline Ovisimo previše o znanosti, a premalo o vjeri. & $10,6 \%$ & $26,4 \%$ & $34,3 \%$ & $19,9 \%$ & $8,8 \%$ & 2,9 & 1,1 \\
\hline $\begin{array}{l}\text { Znanost i tehnologija previše su složeni da bi ih većina } \\
\text { ljudi mogla razumjeti. }\end{array}$ & $19,7 \%$ & $48,5 \%$ & $22,8 \%$ & $6,9 \%$ & $2,1 \%$ & 2,2 & 0,9 \\
\hline $\begin{array}{l}\text { Čini mi se da znanstvenici isprobavaju i stvaraju nove } \\
\text { stvari bez razmišljanja o posljedicama. }\end{array}$ & $14,8 \%$ & $44,2 \%$ & $28,0 \%$ & $10,4 \%$ & $2,6 \%$ & 2,4 & 1,0 \\
\hline $\begin{array}{l}\text { Interes mladih ljudi za znanost i znanstvenu profesiju } \\
\text { bitan je za naš budući prosperitet. }\end{array}$ & $20,9 \%$ & $51,1 \%$ & $23,2 \%$ & $3,8 \%$ & $1,0 \%$ & 2,1 & 0,8 \\
\hline $\begin{array}{l}\text { Znanstveni napredak ima tendenciju da više koristi } \\
\text { bogatima, nego što koristi siromašnima. }\end{array}$ & $15,9 \%$ & $43,4 \%$ & $29,2 \%$ & $9,9 \%$ & $1,6 \%$ & 2,4 & 0,9 \\
\hline U cjelini, znanost čini naš život lakšim. & $16,7 \%$ & $52,1 \%$ & $24,1 \%$ & $6,0 \%$ & $1,2 \%$ & 2,2 & 0,8 \\
\hline $\begin{array}{l}\text { Cak i ako ne donose neposrednu korist, znanstvena } \\
\text { istraživanja koja unapređuju znanje trebaju biti } \\
\text { financirana od države. }\end{array}$ & $15,1 \%$ & $41,1 \%$ & $27,6 \%$ & $13,9 \%$ & $2,3 \%$ & 2,5 & 1 \\
\hline $\begin{array}{l}\text { Pri donošenju odluka o znanstvenim pitanjima } \\
\text { političari bi trebali mišljenje znanstvenika staviti iznad } \\
\text { mišljenja šire javnosti. }\end{array}$ & $11,2 \%$ & $36,4 \%$ & $37,1 \%$ & $10,9 \%$ & $4,3 \%$ & 2,6 & 1 \\
\hline $\begin{array}{l}\text { Znanstvenici prilagođavaju rezultate svojih istraživanja } \\
\text { kako bi potvrdili svoja očekivanja. }\end{array}$ & $10,0 \%$ & $39,2 \%$ & $33,4 \%$ & $14,5 \%$ & $2,9 \%$ & 2,6 & 0,9 \\
\hline $\begin{array}{l}\text { Državna izdvajanja za znanost treba smanjiti jer je } \\
\text { novac bolje potrošiti na nešto drugo. }\end{array}$ & $8,2 \%$ & $22,9 \%$ & $27,8 \%$ & $29,5 \%$ & $11,6 \%$ & 3,1 & 1,1 \\
\hline Koristi od znanosti veće su od eventualnih šteta. & $13,0 \%$ & $43,1 \%$ & $34,9 \%$ & $7,5 \%$ & $1,5 \%$ & 2,4 & 0,9 \\
\hline $\begin{array}{l}\text { Želio/la bih da znanstvenici provode više vremena } \\
\text { objašnjavajući društvene i etičke posljedice svojih } \\
\text { istraživanja nego što to čine sada. }\end{array}$ & $16,9 \%$ & $45,5 \%$ & $28,9 \%$ & $6,8 \%$ & $1,8 \%$ & 2,3 & 0,9 \\
\hline $\begin{array}{l}\text { Zahvaljujući znanosti i tehnologiji otvorit će se više } \\
\text { radnih mjesta za sljedeće generacije. }\end{array}$ & $13,7 \%$ & $43,2 \%$ & $27,1 \%$ & $11,7 \%$ & $4,3 \%$ & 2,5 & 1 \\
\hline $\begin{array}{l}\text { Znanstvena istraživanja izravno doprinose } \\
\text { gospodarskom rastu Hrvatske. }\end{array}$ & $12,4 \%$ & $45,1 \%$ & $30,1 \%$ & $10,0 \%$ & $2,4 \%$ & 2,4 & 0,9 \\
\hline $\begin{array}{l}\text { Predmeti koje sam učio/la u školi, kao što su biologija, } \\
\text { fizika i kemija, ne koriste mi u svakodnevnom životu. }\end{array}$ & $12,3 \%$ & $32,5 \%$ & $23,8 \%$ & $24,4 \%$ & $7,0 \%$ & 2,8 & 1,1 \\
\hline $\begin{array}{l}\text { Hrvatska treba razvijati znanstveni i tehnološki sektor } \\
\text { kako bi poboljšala svoju međunarodnu konkurentnost. }\end{array}$ & $21,6 \%$ & $50,7 \%$ & $23,3 \%$ & $2,9 \%$ & $1,6 \%$ & 2,1 & 0,8 \\
\hline $\begin{array}{l}\text { U svakodnevnom životu važno je pratiti nove } \\
\text { znanstvene spoznaje. }\end{array}$ & $12,2 \%$ & $48,2 \%$ & $26,5 \%$ & $10,2 \%$ & $2,8 \%$ & 2,4 & 0,9 \\
\hline $\begin{array}{l}\text { Vlada bi trebala odgoditi uvođenje novih lijekova ili } \\
\text { tehnologija dok znanstvenici ne budu potpuno sigurni } \\
\text { da nema štetnih nuspojava. }\end{array}$ & $34,3 \%$ & $42,8 \%$ & $18,5 \%$ & $2,8 \%$ & $1,6 \%$ & 1,9 & 0,9 \\
\hline $\begin{array}{l}\text { Znanstvenicima bi trebalo biti dopušteno } \\
\text { eksperimentiranje na životinjama ako to može pomoći } \\
\text { izliječiti život. }\end{array}$ & $16,7 \%$ & $35,0 \%$ & $25,6 \%$ & $14,4 \%$ & $8,3 \%$ & 2,6 & 1,2 \\
\hline $\begin{array}{l}\text { Javnost je dovoljno uključena u odluke o znanosti i } \\
\text { tehnologiji. }\end{array}$ & $3,5 \%$ & $20,7 \%$ & $27,9 \%$ & $33,7 \%$ & $14,2 \%$ & 3,3 & 1,1 \\
\hline $\begin{array}{l}\text { Javne rasprave, pa tako i o znanstvenoj politici, su } \\
\text { prvenstveno propagandne aktivnosti i ne stvaraju } \\
\text { nikakve promjene u znanstvenoj politici. }\end{array}$ & $8,6 \%$ & $32,8 \%$ & $41,9 \%$ & $14,2 \%$ & $2,5 \%$ & 2,7 & 0,9 \\
\hline $\begin{array}{l}\text { Za mene osobno važno je da budem uključen/a u } \\
\text { odlučivanje o znanosti } i \text { tehnologiji. }\end{array}$ & $5,5 \%$ & $22,8 \%$ & $29,5 \%$ & $29,3 \%$ & $13,0 \%$ & 3,2 & 1,1 \\
\hline
\end{tabular}


Promotrimo li tablicu 4, vidljivo je da su ispitanici nešto skloniji slaganju nego neslaganju s ponuđenim tvrdnjama. Također, nemali udio ispitanika opredijelio se i za neutralan odgovor. Najprihvaćenijima se, osim tvrdnje da vlada treba odgoditi uvođenje novih lijekova dok znanstvenici nisu potpuno uvjereni u njihovu neštetnost, pokazuju upravo tvrdnje koje ukazuju na percipiranu važnu ulogu znanosti u društveno-ekonomskom razvoju -,Interes mladih ljudi za znanost bitan je za budući prosperitet“ te „Hrvatska treba razvijati znanstveni i tehnološki sektor s ciljem poboljšanja međunarodne konkurentnosti“. Većina (57\%) se slaže i s tvrdnjama da znanost doprinosi gospodarskom rastu i generira nova radna mjesta te da općenito olakšava život (69\%). Također više od polovice ispitanika smatra da država treba financirati i znanstvena istraživanja koja ne donose neposrednu korist. $S$ druge strane, više od polovice ispitanika (55\%) izrazilo je zabrinutost za budućnost čovječanstva u kontekstu razvoja znanosti, iako većina smatra da znanost ipak donosi više koristi nego štete. Također, njih 59\% slažu se s tvrdnjom da znanstvenici ne razmišljaju o posljedicama svoga rada, kao i da znanost više služi bogatima. Više od dvije trećine ispitanika smatra da su znanost i tehnologija previše složeni za razumijevanje, a njih $45 \%$ smatra da im prirodoznanstveni predmeti koje su učili u školi (biologija, fizika, kemija i dr.) ne koriste u svakodnevnom životu.

Zabrinjavajuće je da čak polovica ispitanika misli da znanstvenici prilagođavaju rezultate svojih istraživanja kako bi potvrdili svoja očekivanja. Iako takav stav može biti izraz sve jače skepse javnosti, na temelju ovih podataka ne možemo ulaziti u analizu toga je li ona rezultat učestalijih kršenja etičkih normi od znanstvene zajednice ili samo reakcija na njihovu veću (medijsku) vidljivost, te posljedično javnu sumnju u znanstvenike.

Nadalje, gotovo dvije trećine ispitanika smatra da bi znanstvenici više trebali raditi na komuniciranju etičkih i društvenih posljedica svoga rada. No više od polovice ispitanika dopustilo bi eksperimente na životinjama ukoliko to pomaže (iz)liječenju ljudi. Kada je u pitanju javna participacija, gotovo polovica ispitanika (48\%) smatra da javnost nije dovoljno uključena u odluke o znanosti i tehnologiji, no $s$ druge strane kada je u pitanju osobno uključivanje u odlučivanje o znanosti i tehnologiji, veći je udio ispitanika nesklonih (42\%) nego onih sklonih osobno se angažirati (28\%). Važan čimbenik u tome jest što je znanost tema u kojoj se velik dio javnosti ne osjeća dovoljno kompetentnim za sudjelovanje i utjecanje na odluke te ne žele biti „kognitivni agenti“ (Jasanoff, 2005.), što može biti i posljedica (nekad) dominantnog modela javne komunikacije znanosti - modela deficita. No i tih (deklarativnih) $28 \%$ zavidan je udio, u odnosu na 16\% građana EU-a spremnih za sudjelovanje u znanstveno-političkim raspravama prema podacima Eurobarometra (2007.). Osim toga, preko 40\% ispitanika izrazilo je sumnju u efekte javnih rasprava, a velik udio ispitanika zaokružio je i neutralnu opciju. Naposljetku, gotovo polovica ispitanika mišljenja je da političari ipak trebaju mišljenje znanstvenika, kada su u pitanju znanstveno-tehnološke teme/odluke, staviti iznad mišljenja javnosti, čime priznaju autoritet i kompetentnost znanstvenika. 
Na tim tvrdnjama provedena je faktorska analiza stavova (pod komponentnim modelom, GK kriterij) te je napravljena varimax transformacija bazične solucije. Tako dobivena faktorska solucija tumačila je 45,16\% varijance i sadržavala četiri faktora. No ta faktorska solucija nije zadovoljavala kriterij jednostavne strukture. Budući da su neke varijable imale slične (male) saturacije (ispod 0,4 ) na više faktora, te su se stvarali faktori specificiteta, napravili smo pročišćavanje te smo postupnim izostavljanjem dviju tvrdnji s malim saturacijama na više faktora povećavali saturacije drugih varijabli na faktore i dobili „čistiju“ faktorsku soluciju. Nakon izostavljanja varijabli 19 i 20 („Vlada bi trebala odgoditi uvođenje novih lijekova ili tehnologija, dok znanstvenici ne budu potpuno sigurni da nema štetnih nuspojava“ i „Znanstvenicima bi trebalo biti dopušteno eksperimentiranje na životinjama ako to može pomoći izliječiti život") i ponovljene faktorizacije reduciranog instrumenta koji je sadržavao 21 tvrdnju dobivena je finalna faktorska solucija, koja je zadržavala tri statistički značajna faktora. Ta tri faktora protumačila su ukupno $41,99 \%$ varijance.

U NSF-ovim i Eurobarometrovim istraživanjima stavova javnosti prema znanosti u pravilu se dobivaju dvofaktorske strukture (Prpić, 2005.), no kako je u ovom istraživanju uključen i manji set tvrdnji vezan uz javnu participaciju, nije začudna pojava trećeg faktora.

Prvi faktor čini deset tvrdnji te tumači 19,3\% ukupne varijance. Cronbachov alfa iznosio je 0,797 te se izostavljanjem bilo koje od tvrdnji ne povećava pouzdanost skale. Ta dimenzija određena je pretežno sadržajima koji govore o socioekonomskim koristima koje donose znanost i tehnologija (tablica 5), te smo je stoga imenovali „znanstveni optimizam“. Međutim, iako se većina čestica odnosi na socioekonomske aspekte i učinke znanosti i tehnologije, taj faktor suodređuju i dvije čestice koje se na prvi pogled ne uklapaju u ovu strukturu, a imaju saturacije i na drugim dvama faktorima (tablica 5). Prvi je želja za učestalijim objašnjavanjem društvenih i etičkih posljedica istraživanja, a drugi je respektiranje znanstvenika kao kompetentnih i autoriteta u njihovom području djelovanja. Drugim riječima, znanstveno-tehnološki optimizam spojen je i s propitivanjem, ali i uvažavanjem autoriteta znanstvenika, što je u skladu s novim tendencijama uvažavanja, ali i svjesnog propitivanja uloge i posljedica znanstvenog djelovanja. Pristalice vide znanost kao pokretač razvoja, uvažavaju znanstvenike, ali žele i njihovu aktivniju ulogu i dijalog s javnošću kada su u pitanju društvene posljedice znanstvene djelatnosti.

Ti nalazi ujedno su i dodatna potvrda istraživanju koje je provela Prpić na javnosti i društvenim elitama (2005., 2007., 2011.) i dobila sličnu tipologiju gledišta: znanstveno-tehnološki optimizam, spoznajna skepsa te tradicionalistička slika znanosti, na ograničenijem, ali i nešto drugačije konstruiranom instrumentu od deset tvrdnji. 
Tablica 5.

Struktura stavova prema znanosti - faktor 1 „znanstveni optimizam“

\begin{tabular}{|l|c|}
\hline $\begin{array}{l}\text { Hrvatska treba razvijati znanstveni i tehnološki sektor kako bi poboljšala svoju međunarodnu } \\
\text { konkurentnost. }\end{array}$ &, 724 \\
\hline U cjelini, znanost čini naš život lakšim. &, 684 \\
\hline Interes mladih ljudi za znanost i znanstvenu profesiju bitan je za naš budući prosperitet. &, 640 \\
\hline U svakodnevnom životu važno je pratiti nove znanstvene spoznaje. &, 637 \\
\hline $\begin{array}{l}\text { Čak i ako ne donose neposrednu korist, znanstvena istraživanja koja unapređuju znanje } \\
\text { trebaju biti financirana od države. }\end{array}$ &, 625 \\
\hline Zahvaljujući znanosti i tehnologiji otvorit će se više radnih mjesta za sljedeće generacije. &, 600 \\
\hline Znanstvena istraživanja izravno doprinose gospodarskom rastu Hrvatske. &, 585 \\
\hline Koristi od znanosti veće su od eventualnih šteta. &, 519 \\
\hline $\begin{array}{l}\text { Želio/la bih da znanstvenici provode više vremena objašnjavajući društvene i etičke } \\
\text { posljedice svojih istraživanja nego što to čine sada. }\end{array}$ &, $474^{10}$ \\
\hline $\begin{array}{l}\text { Pri donošenju odluka o znanstvenim pitanjima političari bi trebali mišljenje znanstvenika } \\
\text { staviti iznad mišljenja šire javnosti. }\end{array}$ &, $455^{11}$ \\
\hline
\end{tabular}

Drugi faktor činilo je devet tvrdnji koje tumače 15,2\% varijance, a Cronbachov alfa iznosio je 0,754. S obzirom na sadržaj tvrdnji koje su visoko saturirane na taj faktor, ovu latentnu dimenziju nazvali smo znanstveni skepticizam (tablica 6). Riječ je o tvrdnjama koje su određene gledištima koje izražavaju nepovjerenje i sumnju u etičnost znanstvenog djelovanja (prilagođavanje rezultata istraživanja, nerazmišljanje o posljedicama), u korisnost i primjenjivost prirodoznanstvenih predmeta u svakodnevnom životu, u ravnomjernu distribuciju društvenog boljitka koji donosi znanost, odnosno izražavaju sumnju u opću dobrobit i pozitivnu društvenu ulogu znanosti, među ostalim i jer se previše udaljava od tradicionalnih vrednota (,zabrinutost za budućnost“, „ovisimo previše o znanosti“). Za taj faktor karakteristične su i tvrdnje koje ukazuju na složenost, tj. nerazumijevanje sadržaja kojima se bavi znanost, što se može dovesti u vezu s izraženijom skepsom prema znanosti, manjom sklonošću za javnim financiranjem znanosti, ali i sumnjom u učinkovitost javnih rasprava.

Visoka saturacija na istom faktoru, odnosno korelacija tvrdnji o složenosti i nerazumijevanju znanosti te skepse prema znanosti govore u prilog tome da su pojedinci koji znanost smatraju nerazumljivom ujedno i skeptičniji prema njoj, što ne znači nužno uzročno-posljedičan odnos, ali dijelom potkrepljuje teze iznesene u modelu deficita.

\footnotetext{
10 0,367 na skali skepticizma.

110,344 na skali participacije.
} 
Tablica 6.

Struktura stavova prema znanosti - faktor 2 „znanstveni skepticizam“

\begin{tabular}{|l|l|}
\hline $\begin{array}{l}\text { Čni mi se da znanstvenici isprobavaju i stvaraju nove stvari bez razmišljanja o } \\
\text { posljedicama. }\end{array}$ &, 689 \\
\hline $\begin{array}{l}\text { Znanstvenici prilagođavaju rezultate svojih istraživanja kako bi potvrdili svoja } \\
\text { očekivanja. }\end{array}$ &, 686 \\
\hline $\begin{array}{l}\text { Znanstveni napredak ima tendenciju da više koristi bogatima, nego što koristi } \\
\text { siromašnima. }\end{array}$ &, 659 \\
\hline $\begin{array}{l}\text { Državna izdvajanja za znanost treba smanjiti jer je novac bolje potrošiti na nešto drugo. } \\
\text { Što više znam o znanosti, zabrinutiji/a sam za budućnost čovječanstva. }\end{array}$ &, 584 \\
\hline $\begin{array}{l}\text { Javne rasprave, pa tako i o znanstvenoj politici, prvenstveno su propagandne aktivnosti } \\
\text { i ne stvaraju nikakve promjene u znanstvenoj politici. }\end{array}$ &, 558 \\
\hline $\begin{array}{l}\text { Predmeti koje sam učio/la u školi, kao što su biologija, fizika i kemija, ne koriste mi u } \\
\text { svakodnevnom životu. }\end{array}$ &, 505 \\
\hline \begin{tabular}{l} 
Onisimo previše o znanosti, a premalo o vjeri. \\
\hline
\end{tabular} &, 501 \\
\hline
\end{tabular}

Naposljetku, treći faktor, koji bi se mogao opisati kao javna participacija, činile su samo dvije tvrdnje vezane uz uključenost u odlučivanje i tumačile su 7,5\% ukupne varijance (tablica 7). Iako eksplorativna faktorska analiza načelno dopušta ekstrakciju i zadržavanje faktora s dvjema česticama, budući da je riječ o faktoru koji čine samo dvije tvrdnje te da već zbog samog broja čestica ima nisku pouzdanost (Cronbachov alfa $=, 415$ ), bilo bi ga nezahvalno koristiti u daljnjim statističkim analizama, iako tvori sadržajnu cjelinu. Stoga taj faktor nismo koristili u daljnjim analizama i interpretacijama u ovom radu. No pitanje javne participacije bit će tema jedne od budućih studija.

Tablica 7.

Struktura stavova prema znanosti - faktor 3 ,javna participacija“

Javnost je dovoljno uključena u odluke o znanosti i tehnologiji. 


\section{Odnos znanstvene pismenosti i stavova javnosti prema znanosti}

Naposljetku, pokušat ćemo odgovoriti i na glavno pitanje ovoga rada: postoji li veza stavova i pismenosti, pri čemu smo u analizu uključili i sociodemografske varijable kao potencijalne prediktore stavova. Kako bismo provjerili postoji li veza između stavova prema znanosti, sociodemografskih prediktora i znanstvene pismenosti, provedena je multipla regresijska analiza (enter metoda). Dva dobivena faktora (znanstveni optimizam i znanstveni skepticizam) bila su kriterijske varijable, a sociodemografske odrednice i skala znanstvene pismenosti prediktori.

Nalazi regresijske analize pokazuju da su za skalu znanstvenog optimizma značajni prediktori obrazovanje i indeks znanstvene pismenosti, iako i oni tumače mali (ali značajan) dio varijance (tablica 8). Budući da skala znanstvenog optimizma ide od slaganja s tvrdnjama (1) prema neslaganju (5) i da je beta ponder negativnog predznaka, to znači da što je veći rezultat na skali znanstvene pismenosti, tj. što su ispitanici znanstveno pismeniji, to je veće i slaganje s tvrdnjama koje definiraju faktor znanstvenog optimizma. Značajan je prediktor i razina obrazovanja, odnosno školska sprema ispitanika, na način da su obrazovaniji ispitanici skloniji znanstvenom optimizmu. Slične nalaze o značaju obrazovanja i znanstvene pismenosti pokazala su i neka druga inozemna i domaća istraživanja (Allum i sur., 2008.), čime se pružala potvrda postavkama modela deficita, iako je zbog proturječnosti nalaza nekih drugih studija povremeno teško izvesti jednoznačne zaključke. Na tom tragu autori (Prpić, 2005.) apeliraju na dodatne i dublje analize utjecaja obrazovanja na stavove prema znanosti, ukazujući na mogućnost da u složenijim istraživanjima model gubi uvjerljivost. $S$ druge strane, većina empirijskih studija ukazuje na značajne spolne razlike u stavovima prema znanosti, pri čemu žene tendiraju iskazivati negativnije stavove prema znanosti (i tehnologiji), osobito kod kontroverznih tema (Bak, 2001.). No studije koje su kontrolirale utjecaj drugih sociodemografskih varijabli, kao što su primjerice religioznost i obrazovanje, pronašle su da spol tada prestaje biti značajan prediktor stavova (Hayes i Tariq, 2000., 2001.). Nalazi ove studije govore u prilog potonjih empirijskih istraživanja jer se spol u ovom istraživanju nije pojavio kao značajan prediktor stavova prema znanosti. Ujedno naši nalazi potvrđuju uvide domaće studije o nepostojanju, tj. minimalnim spolnim diferencijacijama u percepcijama znanosti u hrvatskoj populaciji (Prpić, 2005.). Prpić (2005.) moguće objašnjenje vidi u tradiciji ideološke ili deklarativne podrške znanosti, odnosno formiranju proznanstvenih stavova koji su mogli generirati i manje spolne razlike.

Nadalje, veličina naselja kao ni stupanj samoidentificirane religioznosti nisu se pokazali značajnima. Iako neke studije ukazuju na negativnije stavove prema znanosti ruralnog i religioznog dijela stanovnika, druge ukazuju na to da su one uglavnom posredovane drugim sociodemografskim varijablama, kao što su obrazovanje (i dob). 
Tablica 8.

Rezultati regresijske analize - faktor „znanstveni optimizam“

\begin{tabular}{|c|c|c|c|c|}
\hline \multicolumn{2}{|c|}{$\mathrm{R}$} & $\mathrm{R}^{2}$ & $\mathrm{~F}$ & Sig \\
\hline \multicolumn{1}{|c|}{, 217} &, 047 & 6,778 &, 000 \\
\hline \multirow{6}{*}{ Model } & Stand. beta koeficijent & $\mathrm{t}$ & Sig. \\
\hline \multirow{4}{*}{ Enter } & (Constant) & & 4,256 &, 000 \\
\cline { 2 - 5 } & Spol &,- 058 & $-1,609$ &, 108 \\
\cline { 2 - 5 } & Stupanj obrazovanja &,- 121 &,- 399 &, 690 \\
\cline { 2 - 5 } & Veličina naselja &,- 037 & $-2,924$ &, 004 \\
\cline { 2 - 5 } & Religioznost &,- 033 &,- 949 &, 389 \\
\cline { 2 - 5 } & ZP_indeks &,- 094 &,- 861 &, 014 \\
\hline
\end{tabular}

I kada je u pitanju drugi faktor, znanstveni skepticizam, indeks znanstvene pismenosti i razina obrazovanja identificiraju se kao značajni prediktori (tablica 9).

Tablica 9.

Rezultati regresijske analize - faktor „znanstveni skepticizam“

\begin{tabular}{|c|c|c|c|c|}
\hline & $\mathrm{R}$ & $\mathrm{R}^{2}$ & $\mathrm{~F}$ & Sig \\
\hline & ,325 & , 105 & 15,337 & ,000 \\
\hline Mode & & Stand. beta koeficijent & $\mathrm{t}$ & Sig. \\
\hline & (Constant) & & $-6,506$ &, 000 \\
\hline & Spol &,- 055 & $-1,568$ & ,117 \\
\hline & Dob &, 042 & 1,181 & 238 \\
\hline Enter & Stupanj obrazovanja &, 176 & 4,403 &, 000 \\
\hline & Veličina naselja & 029 &, 770 & ,442 \\
\hline & Religioznost &, 072 & 1,942 &, 052 \\
\hline & ZP_indeks & 180 & 4,842 & ,000 \\
\hline
\end{tabular}


Budući da skala ide od slaganja s tvrdnjama (1) prema neslaganju (5), što je veći rezultat na skali znanstvene pismenosti, to je viši rezultat, tj. veće neslaganje $s$ tvrdnjama koje definiraju faktor znanstvenog skepticizma. Drugim riječima, znanstveno pismeniji ispitanici skloniji su iskazati neslaganje sa znanstveno skeptičnim tvrdnjama. Značajan prediktor opet je i razina obrazovanja, na način da se obrazovaniji ispitanici manje slažu sa znanstvenim skepticizmom. Objašnjenje zašto su manje obrazovani ispitanici skloniji skeptičnijem viđenju znanosti može dijelom proizlaziti iz (tradicionalnijeg) vrijednosnog sustava, ali i iz tendencije da „sebe vide kao one koje imaju manje koristi od znanosti“ (Bak, 2001.: 792). U prilog potonjem govori i prihvaćanje tvrdnje „Znanstveni napredak ima tendenciju da više koristi bogatima, nego što koristi siromašnima“. Drugim riječima, manje obrazovani ispitanici osjećaju se isključeni iz blagodati koje donosi znanost. Veličina naselja, spol, dob te religioznost nisu identificirani kao značajni prediktori. No prediktor koji je blizu granične značajnosti jest religijska samoidentifikacija, i to na način da se ispitanici manje skloni vjeri manje slažu sa znanstvenim skepticizmom. ${ }^{12}$

Zaključno, nalazi regresijske analize koja dovodi u vezu stupanj obrazovanja i razinu znanstvene pismenosti kao značajne prediktore stavova prema znanosti dijelom govore u prilog modelu deficita i uvidu dosad provedenih inozemnih studija, ali i upućuju na moguće kontekstualne specifičnosti, kao što su minimalne spolne razlike.

\section{Zaključak}

Sumarno, nalazi ove studije otkrivaju nam nekoliko značajnih uvida.

Prvo. Iako razina znanstvene pismenosti nije visoka, javnim stavovima i dalje dominira pretežno pozitivno viđenje znanosti, posebice kao pokretača društveno-ekonomskog razvoja. To možemo dovesti u vezu s proznanstvenim stavovima koji korijene vuku još iz socijalističkog razdoblja, gdje se znanost promatra i doživljava kao važan pokretač društvenog razvoja. $S$ druge strane zamjetna je i skepsa prema ulozi i posljedicama znanosti, što domaći istraživači primarno pripisuju procesu retradicionalizacije (Prpić, 2005.), a ne kritičkom osvješćivanju i propitivanju tipičnom za visoko razvijena društva. No riječ je o uvidu kojem treba ozbiljnije pristupiti u novim istraživanjima ishodišta javnih skepsi prema znanosti.

Drugo. Sociodemografski indikatori - za razliku od nalaza inozemnih empirijskih studija naša studija nije zabilježila spolne razlike kada su u pitanju znanstvena pismenost te stavovi prema znanosti, ali jest potvrdila utjecaj obrazovne razine. Nepostojanje

12 Naposljetku, treći „okrnjeni faktor“ javne participacije nije imao značajne prediktore $\left(R^{2}=0,011\right.$; $\mathrm{F}=1,427$; sig. $=0,201$ ), što i nije začuđujuće s obzirom na to da su ga sačinjavale samo dvije varijable, čime je potvrđena opravdanost isključivanja iz daljnjih interpretacija. 
spolnih razlika u znanstvenoj pismenosti možemo dijelom povezati s konstrukcijom mjernog instrumenta u kojem su ravnomjernije zastupljeni sadržaji različitih znanstvenih disciplina. S druge strane, nepostojanje spolne diferencijacije u stavovima povezuje se $s$ tradicijom ideološke ili deklarativne podrške znanosti.

Treće. Uključivanjem više sociodemografskih determinanti u ovu studiju nastojali smo testirati, ali i djelomično se odmaknuti od tradicionalnog modela deficita, koji je dovodio u vezu prvenstveno razinu znanstvene pismenosti i stavove prema znanosti. Pronađena je značajna, ali ne i jaka veza između poznavanja temeljnih znanstvenih činjenica, obrazovanja i pozitivnog stava prema znanosti. U tom smislu i ova studija potvrđuje nalaze metaanalize (Allum i sur., 2008.) koja ukazuje na vezu obrazovanja, znanstvene pismenosti i pozitivnih stavova prema znanosti, te dijelom govori u prilog kritiziranom modelu deficita. Drugim riječima, neke postavke modela deficita, osobito kad su u pitanju generalizirani stavovi prema znanosti, i dalje se potvrđuju. To bi značilo da akcije „opismenjivanja“ neznanstvene javnosti, uključivanja javnosti u dijalog sa znanstvenicima imaju određenog efekta na stavove prema znanosti.

Unatoč tome treba imati na umu da pozitivni stavovi prema znanosti općenito ne znače nužno pozitivan stav prema određenoj znanstvenoj temi / znanstvenom istraživanju, osobito kada su u pitanju (moralno) kontroverzna znanstvena istraživanja, kao što sugeriraju studije. Generalizacije, posebice kada su u pitanju etički osjetljive teme, nisu uvijek prikladne. Također, oprez je potreban jer neke studije sugeriraju da se usložnjavanjem pristupa mogu dobiti i drugačiji nalazi. Moguće objašnjenje zašto se model deficita pokazao primjenjivim u Hrvatskoj možda leži upravo u sociokulturnom kontekstu, odnosno može se povezati s tezom o povezivanju znanja i stavova $s$ karakteristikama socioekonomskog i kulturnog konteksta u različitim zemljama, odnosno u činjenici da se nalazimo upravo na tom stupnju razvoja gdje je on primjenjiv. I najrecentnije studije (Guenther i Weingart, 2018.) ukazuju na važnost sagledavanja sociokulturnog konteksta te diferencijaciju javnosti i njihovih stavova prema znanosti.

Za cjelovitije razumijevanje stavova prema znanosti nužne su daljnje analize koje bi uključile različite pristupe (kvalitativne i kvantitativne), razine (stavovi prema znanosti općenito naspram stavova prema specifičnim temama) kao i druge indikatore (npr. povjerenje, vrijednosti), odnosno razvoj složenije teorijsko-empirijske matrice. Zbog toga danas u znanstvenim publikacijama sve više dominiraju studije slučaja o stavovima prema specifičnim temama. $S$ druge strane, ukoliko se ostane samo na razini pojedinačnih uvida, gubi se potrebna širina. Stoga je nužna izrada kompleksnije matrice kao i kombiniranje različitih pristupa i studija za potpun i točan uvid u javne stavove prema znanosti. 


\section{Literatura}

1. Allum, N.; Sibley, E.; Sturgis, P.; Stoneman, P. (2014). Religious Beliefs, Knowledge about Science and Attitudes Towards Medical Genetics. Public Understanding of Science, 23 (7): 833-849.

5. Allum, N.; Sturgis, P.; Tabourazi, D.; Brunton-Smith. I. (2008). Science knowledge and attitudes across cultures: a meta analysis. Public Understanding of Science, 17 (1): 35-54.

6. Bahtijarević, Š. (1969). Rasprostranjenost religioznosti na području zagrebačke regije. Zagreb: IDIS.

7. Bak, H. (2001). Education and Public Attitudes toward Science: Implications for the 'Deficit Model' of Education and Support for Science and Technology. Social Science Quarterly, 82 (4): 779-95.

8. Bauer, M. (2008). Survey research and the public understanding of science, in: Bucchi, M. and Trench, B. (Eds.). Handbook of public communication of science and technology. London: Routledge.

9. Bauer, M. (2015). Science literacy and beyond. Public understanding of science, 24 (3): 258-259.

10. Bauer, M. (2009). The evolution of public understanding of science - discourse and comparative evidence. Science, technology and society, 14 (2): 221-240.

11. Bauer, M.; Petkova, K. and Boyadjieva, P. (2000). Public knowledge and attitudes to science: alternative measures that may end the "science war". Science, Technology, \& Human Values, (25) 1: 30-51.

12. Bauer, M. W.; Petkova, K.; Boyadjieva, P.; Gornev, G. (2006). Long-term trends in the public representation of science across the 'iron curtain': Britain and Bulgaria, 1946-95. Social studies of science, 36 (1): 99-131.

13. Bauer, M. and Howard, S. (2013). The culture of science in modern Spain. An analysis of Public Attitudes Across Time, Age Cohorts and Regions. Bilbao: Foundation BBVA.

14. Brajdić Vuković, M. i Šuljok, A. (2005). Slika znanosti u dnevnom tisku: popularizacija ili marginalizacija?, u: Prpić, Katarina (Ur.) Elite znanja u društvu (ne) znanja. Zagreb: Institut za društvena istraživanja, 291-322.

15. Brossard, D. and Shanahan, J. (2006). Do they know what they read? Building a scientific literacy measurement instrument based on science media coverage. Science Communication, 28 (1): 47-63.

16. Bucchi, M. and Neressini, F. (2002). Biotech remains unloved by the more informed. Nature, 416: 261.

17. Burns, T. W.; O'Connor D. J. and Stocklmayer, S. (2003). Science Communication: A Contemporary Definition. Public Understanding of Science, 12 (2): 183-202.

18. Durant, J.; Bauer, M.; Gaskell, G.; Midden, C.; Liakopoulos, M.; Scholten, L. (2000). Two cultures of public understanding of science and technology in Europe, in: Dierkes, M. and Von Grote, C. (Eds.) Between Understanding and Trust: The Public, Science and Technology. London: Routledge, 131-156. 
19. Einsiedel, E. (1994). Mental maps of science: knowledge and attitudes among Canadian adults. International Journal of Public Opinion Research, 6: 35-44.

20. Eurobarometer (1992). Special Eurobarometer 76, Europeans, Science and Technology, survey and report, European Commission, June 1993. https:/lec.europa. eu/commfrontoffice/publicopinion/archives/ebs/ebs 076 en.pdf.

21. Eurobarometer (2005). Special Eurobarometer 224, Europeans, Science and Technology, survey and report, European Commission, June 2005. http://ec.europa. eu/public opinion/archives/ebs/ebs 224 en.pdf.

22. Eurobarometer (2007). Special Eurobarometer 282.Scientific research in the media. European Commission, december 2007. https://ec.europa.eu/commfrontoffice/publicopinion/archives/ebs/ebs 282 en.pdf.

23. Evans, G. and Durant, J. (1995). The relationship between knowledge and attitudes in the public understanding of science in Britain. Public Understanding of Science, 4 (1): 57-74.

24. Gauchat, G. (2012). Politicization of Science in the Public Sphere: A Study of Public Trust in the United States, 1974 to 2010. American Sociological Review, 77(2):167-187.

25. Godin, B. and Gingras, Y. (2000). What is scientific and technological culture and how is it measured? A multidimensional model. Public Understanding of Science, 9 (1): 43-58.

26. Guenther, L. and Weingart, P. (2018). Promises and reservations towards science and technology among South African publics: A culture-sensitive approach. Public Understanding of Science, 27 (1): 47-58.

27. Hayes, B. C. and Tariq, V. N. (2000). Gender Differences in Scientific Knowledge and Attitudes toward Science: a Comparative Study of Four Anglo-American Nations. Public Understanding of Science, 9 (4): 433-47.

28. Hayes, B. C. and Tariq, V. N. (2001). Gender Differences in Scientific Knowledge and Attitudes toward Science: a Reply to a Reply. Public Understanding of Science, 10 (4): 431-3.

29. Ho, S. S.; Brossard, D. and Scheufele, D. A. (2008). Effects of value predispositions, mass media use, and knowledge on public attitudes toward embryonic stem cell research. International Journal of Public Opinion Research, 20 (2): 171-192.

30. Holton, G. (1993). Can science be at the centre of modern culture? Public Understanding of Science, 2 (4): 291-305.

31. Inönü, E. (2003). The influence of cultural factors on scientific production. Scientometrics, (56) 1: 137-146.

32. Irwin, A. and Michael, M. (2003). Science, Social Theory and Public Knowledge. Maidenhead: Open Press University.

33. Jasanoff, S. (2005). Designs on Nature: Science and Democracy in Europe and the United States. UK: Princeton University Press.

34. Laugksch, R. C. (2000). Scientific literacy: a conceptual overview. Science Education, 84: 71-94. 
35. Losh, S. C. (2010). Diverse digital divides in American society: 1983-2006, in: Ferro, E.; Dwivedi, Y. K.; Gil-Garcia, J. R.; Williams, M. D. (Eds.) Handbook of Research on Overcoming Digital Divides: Constructing an Equitable and Competitive Information Society. Hershey, PA: IGI Global, 196-222.

36. Losh, S. C. (2012). Stereotypes about scientists over time among U.S. adults: 1983 and 2001. Public Understanding of Science, 19 (3): 372-82.

37. Marinović Bobinac, A. (2005). Dimenzija religioznog iskustva u Hrvatskoj: »šapat anđela« iz sociologijske perspektive. Sociologija i prostor, 168: 339-370.

38. Marinović Jerolimov, D. i Ančić, B. (2014). Religioznost i stavovi prema seksualnosti i braku odrasle populacije u Hrvatskoj. Društvena istraživanja, 23 (1): 111-132.

39. Michael, M. (1998). Between citizen and consumer: multiplying the meanings of the "public understanding of science". Public Understanding of Science, 7 (4): 313-327.

40. Michael, M. (2002). Comprehension, apprehension, and prehension: heterogeneity and the public understanding of science. Science, Technology and Human Values, 27 (3): 357-378.

41. Miller, J. D. (1983). Scientific literacy: A conceptual and empirical review. Daedalus, 112 (2): 29-48.

42. Miller, J. D. (1992). Toward a scientific understanding of the public understanding of science and technology. Public Understanding of Science, 1(1): 23-26.

43. Miller, J. D. (1998). The measurement of civic scientific literacy. Public Understanding of Science, 7 (3): 203-223.

44. Miller, J. D. (2004). Public understanding of, and attitudes toward, scientific research, what we know and what we need to know. Public Understanding of Science, 13 (3): 273-294.

45. Miller, J. D.; Pardo, R. and Niwa, F. (1997). Public Perceptions of Science and Technology: a Comparative Study of the European Union, the United States, Japan, and Canada. Madrid: BBV Foundation.

46. National Science Board (2016). Science and Engineering Indicators 2016. Arlington, VA: National Science Foundation.

47. National Science Board (2014). Science and Engineering Indicators 2014. Arlington, VA: National Science Foundation.

48. National Science Board (2012). Science and Engineering Indicators 2012. Arlington, VA: National Science Foundation.

49. OST and Wellcome Trust (2000). Science and the public: A review of science communication and public attitudes to science in Britain. London: The Office of Science and Technology (OST) \& Wellcome Trust.

50. Paisley, W. J. (1998). Scientific literacy and the competition for public attention and understanding. Science Communication, 20 (1): 70-80.

51. Pardo, R. and Calvo, F. (2002). Attitudes toward science among the European public: a methodological analysis. Public Understanding of Science, 11: 155-195. 
52. Pardo, R. and Calvo, F. (2004). The cognitive dimension of public perceptions of science: methodological issues. Public Understanding of Science, 13: 203-227.

53. Pomerantz E. M.; Chaiken, S. and Tordesillas, R. S. (1995). Attitude strength and resistance processes. Journal of Personality and Social Psychology, 69 (3): 408419.

54. Price, A. and Peterson, L. (2016). Scientific progress, risk, and development: Explaining attitudes toward science cross-nationally. International Sociology, 31 (1): 57-80.

55. Prpić, K. (2005). Znanost u očima javnosti i znanstvenika, u: Prpić, K. (Ur.), Elite znanja u društvu (ne)znanja. Zagreb: Institut za društvena istraživanja u Zagrebu: 233-289.

56. Prpić, K. (2007). Kako hrvatska javnost i politička elita percipiraju znanost? Politicka misao, 44 (1): 67-92.

57. Prpić, K. (2011). Science, the public, and social elites: How the general public, scientists, top politicians and managers perceive science. Public understanding of science, 20 (6): 733-750.

58. Roduta Roberts, M.; Reid, G.; Schroeder, M.; Norris, S. (2013). Causal or Spurious? The Relationship of Knowledge and Attitudes to Trust in Science and Technology. Public Understanding of Science, 22 (5): 624-641.

59. Sturgis, P. and Allum, N. (2001). Gender Differences in Scientific Knowledge and Attitudes Toward Science: A Comparative Study of Four Anglo-American Nations: Reply to Hayes and Tariq. Public Understanding of Science, 10: 427-30.

60. Sturgis, P. and Allum, N. (2004). Science in society: re-evaluating the deficit model of public attitudes. Public Understanding of Science, 13 (1): 55-74.

61. Šporer, Ž. (2004). Knowledge-based Economy and Social Capital in Central and Eastern European Countries, in: Švarc, J.; Lažnjak, J.; Šporer, Ž.; Polšek, D. (Eds.). Transition Countries in the Knowledge Society: Socioeconomic analysis. Zagreb: Institut društvenih znanosti Ivo Pilar: 127-166.

62. Šuljok, A. (2011). Medijske prezentacije znanosti i društvene promjene u Hrvatskoj. Doktorska disertacija.

63. von Roten, F. C. (2004). Gender Differences in Attitudes toward Science in Switzerland. Public Understanding of Science, 13 (2): 191-9.

64. Wynne, B. (1992). Public Understanding of Science Research: New Horizons or Hall of Mirrors?. Public Understanding of Science 1 (1): 37-43.

65. Wynne, B. (1993). Public uptake of science: A case for institutional reflexivity. Public Understanding of Science, 2: 321-337. 
Izvorni znanstveni rad

\title{
Scientific Literacy and Attitudes Towards Science in Croatia
}

\section{Adrijana šuljok}

Institute for Social Research in Zagreb, Croatia

e-mail: adrijana@idi.hr

\begin{abstract}
This paper examines the relationship between scientific literacy and public attitudes toward science in Croatia, as well as their sociodemographic determinants. The research was conducted by personal interview within the omnibus survey on a representative multistage stratified sample of 1000 inhabitants of the Republic of Croatia. The findings of this study indicate a low level of scientific literacy, but still predominantly positive attitudes towards science, with some indications of retradition. The findings also indicate a significant but weak relationship between the level of scientific literacy and (positive) attitudes toward science, which is consistent with the findings of foreign research.
\end{abstract}

Key words: public understanding of science, scientific literacy, attitudes towards science, deficit model. 